\title{
Performans Ölçütlerine Dayalı Bakım Yönetim Modülünün İş Süreçleri Yönetimi Yaklaşımı ile Modellenmesi
}

\author{
Leyla Özgür Polat ${ }^{1}$, Aşkıner Güngör ${ }^{2}$ * \\ ÖZ
}

Günümüzde işletmelerin ürünlerine uygun fiyat vermeleri, ürün teslimatlarını zamanında yapmaları ve kalite konusunda güvenilir olmaları rekabet düzeylerinin temel göstergeleri arasındadır. Rekabetçiliğin sağlanmasında ve korunmasında bakım önemli bir destek sürecidir. Üretim ve hizmet sektöründe bakım faaliyetleri, fiziksel altyapıyı hazır ve nitelikli tutarak üretim faaliyetlerin devamlılığının sağlanması, maliyetlerin indirgenmesi ve müşteri potansiyelinin korunmasında önemli bir rol oynamaktadır. Bu nedenle bakım süreçlerinin yönetim, planlama ve izleme aşamalarının bilişim teknolojileriyle desteklenerek etkin bir şekilde yürütülmesi gerekmektedir.

Çalışma kapsamında iş süreç yönetimi (İSY) ve iş süreç yeniden mühendisliği (İSYM) gereği mevcut durumda manuel olarak yürütülen süreçlerin bilgi teknolojileri ile desteklenerek yeniden tasarlanması sonucu kurumsal kaynak planlama (KKP) sistemlerine entegre çalışacak bakım modüllerine yönelik tasarım gereksinimleri ortaya konulmuştur. Bakım faaliyetlerinin verimliliğini arttırmak ve izlemini kolaylaştırmak amacıyla, iş modellemesi IBM Business Modeler programı ve iş süreç yönetimi simgeleri kullanılarak, sistem performans göstergelerini de dikkate alan bir bakım yönetim sistemi tasarımı gerçekleştirilmiştir. Çalışmada sunulan sistem önerisinin, bakım süreçlerini, dijitalleşme kapsamında bilişim teknolojilerine dayalı geliştirmek ve kurumsal kaynak yönetimi yazılımlarına entegre etmek amacına sahip başta imalat sektörü olmak üzere birçok kuruluş için katkı sağlayacağı düşünülmektedir.

Anahtar Kelimeler: İş Süreç Yönetimi Simgeleri (İSYS), Bakım Planlaması, Kurumsal Kaynak Planlama (KKP), İş Süreç Yönetimi (İSY), İş Süreç Yeniden Mühendisliği (İSYM), Dijitalleşme.

\section{Modelling Performance Criteria Based Maintenance Management Module by Using Business Process Management Approach}

\begin{abstract}
Today, offering the best price, meeting delivery due dates and being trustworthy for quality are among competitiveness' indicators for companies. To keep competitiveness at a high level, maintenance serves as an important support process. Maintenance activities in manufacturing and service sector, by keeping the physical capacity ready and reliable, play an important role in sustaining production, reducing cost, and keeping customers happy. Therefore, maintenance operations like management, planning and monitoring need to be carried out efficiently with the support of information technologies.

In this study, design requirements are described for maintenance modules integrated in enterprise resource planning (ERP) systems as a result of the redesign of the processes that are currently carried out manually using business process management (BPM) and business process reengineering (BPR) supported by information technologies. To increase the efficiency of the maintenance activities and to facilitate monitoring, maintenance management system is designed considering system performance indicators by using the IBM Business Modeler program and business process management notation (BPMN). The proposed system will contribute to many companies primarily in manufacturing whose aim is to improve maintenance processes in the context of digitalization and integrating them into enterprise resource planning software.
\end{abstract}

Keywords: Business Process Management Notation (BPMN), Maintenance Planning, Enterprise Resource Planning (ERP), Business Process Management (BPM), Business Process Reengineering (BPR), Digitalization

\author{
Geliş/Received : : 01.04 .2021 \\ Kabul/Accepted : $\quad$ : 11.05.2021 \\ 1 Pamukkale Üniversitesi, Rektörlük, Bilgi İșlem Daire Başkanlığı, Denizli \\ lozgur@pau.edu.tr, ORCID: 0000-0002-5143-359X \\ 2 Pamukkale Üniversitesi, Mühendislik Fakültesi, Endüstri Mühendisliği Bölümü, Denizli \\ askiner@pau.edu.tr, ORCID: 0000-0002-1223-6796
}




\section{EXTENDED ABSTRACT}

\section{Introduction}

In today's competitive market environment, it has become an obligation for companies to continuously improve their processes to protect their customer potential. One of the most important reasons for this obligation is that technological developments progress too quickly to be followed. In addition, because of the development of technology and the increase of mechanization, companies must take the necessary measures to maintain the healthy working conditions of their production hardware. In this way, high-cost machines and equipment will be able to operate at the desired level of safety and reliability, while maintaining the production quality. For this reason, maintenance activities are important in terms of the efficiency and sustainability of the processes. Therefore, maintenance processes should be defined and analyzed, and especially manual processes should be digitalized by supporting them with information technologies. In the digitalization process, the process should be improved by adopting the business process management (BPM) approach and applying the steps in the process management cycle.

Maintenance activities are carried out to ensure that machines and equipment perform their desired functions in the best and expected level. It covers activities such as repair and lubrication. Generally, maintenance activities are divided into two main groups as unscheduled / breakdown and scheduled maintenance. Scheduled maintenance activities are also divided into three groups. These are periodic, preventive, and predictive maintenance. Unscheduled maintenance is a maintenance technique performed when the machine or equipment becomes unusable because of breakdown. No action is taken before the breakdown occurs and the machine or equipment continues to be operated until the breakdown occurs. This method is widely applied in plants and workshops that have many spares and produce with inexpensive machines. Planned maintenance is a maintenance repair process carried out within the specified plans and programs using measurement techniques, statistical information, and experience. The purpose of planned maintenance is to increase efficiency by reducing machine downtime, to extend the economic life of machines, to ensure compliance with the prepared programs and to reduce maintenance costs. Periodic maintenance is a type of planned maintenance performed within specified periods. Periods are determined in time intervals determined either by the vendor or by the company itself. Preventive maintenance is a planned maintenance carried out with activities such as testing, measuring, adjusting, part replacement to increase the life of the equipment and ensure their optimum use. Predictive maintenance is a planned maintenance method to repair the previously determined breakdown by monitoring the performance of the machines with measurements made during production and deciding when maintenance will be required. To provide convenience and effectiveness in the management of maintenance activities, operations can be done in a shorter and more accurate manner by establishing a maintenance management system.

\section{Objectives/Research Purpose}

In this study, design requirements are described for maintenance modules integrated in enterprise resource planning (ERP) systems as a result of redesigning processes that are currently carried out manually using business process management and business process reengineering supported by information technologies. To increase the efficiency of the maintenance activities and to facilitate monitoring, maintenance management system is designed considering system performance indicators.

\section{Methods/Methodology}

We use the IBM Business Modeler program and business process management notation (BPMN) to accomplish the aim of the study. Business process management is a method that handles and models the work done within the organization with a holistic approach. It aims to define and document corporate processes and to make improvements automatically. BPM, which is also related to financial issues, enables cost and performance follow-up of processes by defining performance criteria. BPM systems aim to model processes as fast, flexible, and affordable. In this way, it ensures that the processes are carried out in a controlled manner, the standardization of the functioning of 
the institution and the creation of a structure that can identify the shortcomings of the processes. Processes such as defining, modeling, analyzing, monitoring, and controlling processes in BPM are the most important item of the development phase. The benefits of BPM to the business include controlling processes, performance tracking, process improvement processes, facilitating communication between information technologies and the business world, enabling efficiency and competence tracking, and standardizing the works. BPM strategies include process improvement and business process reengineering (BPR). Process improvement approach is followed by defining the problems and solving them step by step without questioning the current process structure. The process is continuously improved with the logic of one step at a time and one correction at a time. In BPR, the approach of re-designing the process as a result of radical changes by questioning the fundamental assumptions and principles of the current process is taken into consideration. Within the framework of these approaches, maintenance processes can be defined, discovered, analyzed, redesigned, implemented and controlled.

\section{Results /Findings}

The findings of the systems analysis have been presented as a maintenance management system considering mostly used system performance indicators.

\section{Discussion and Conclusions}

The system proposed can be adapted to different ERP systems or encoded as a general module as it is designed in accordance with the generalized structure. At the same time, analysis processes can be carried out by collecting the necessary measurement data with the help of tools such as IoT and sensors by obtaining support from manufacturing execution system (MES). In future studies, all processes in production can be examined in detail and business modeling and reporting to include interactions with maintenance. 


\section{GİRIŞ}

Günümüzün rekabet koşullarında ayakta kalabilmek ve müşteri potansiyelini korumak adına firmalar kendilerini sürekli iyileștirmek zorundadırlar. Bu zorunluluğun en önemli nedenleri arasında üretim tesislerindeki teknolojik gelişmelerin takip edilemeyecek kadar hızlı bir şekilde ilerleme göstermesi de bulunmaktadır. Ayrıca teknolojinin gelişmesi ve makineleşmenin artması neticesinde, firmalar bu makinelerin sağlıklı çalışma durumlarını devam ettirebilmek için gerekli önlemleri almak zorundadır. Böylece, üretim kalitesi korunup maliyeti yüksek makine ve teçhizatların istenilen güvenlik ve güvenilirlik seviyesinde çalışmaları sağlanabilecektir. Bu nedenle bakım faaliyetleri süreçlerin verimlilikleri ve sürdürülebilirlikleri bakımından önem arz etmektedir. Dolayısı ile de bakım süreçlerinin tanımlanarak analiz edilmesi ve özellikle de manuel olarak yürütülen süreçlerin bilgi teknolojileri ile desteklenerek dijitalleştirilmesi gerekmektedir. Dijitalleştirme sürecinde de öncelikle iş süreç yönetimi yaklaşımın benimsenerek süreç döngüsündeki adımların uygulanması ile sürecin iyileştirilmesi gerekmektedir.

İş Süreç Yönetimi (BPM: Business Process Management), kurum içinde yapılan işleri bütünsel bir yaklaşımla ele alıp modelleyen bir yöntemdir. BPM, kurum süreçlerinin ortaya çıkarılması, belgelendirilmesi ve iyileştirmelerin otomatik yapılmasını hedefler. Finansal konularla da ilişkili olan BPM performans kriterlerinin ortaya çıkarılmasıyla süreçlerin maliyet ve performans takip işlemlerinin yapılabilmesini sağlamaktadır [1, 2]. BPM sistemleri hızlı, esnek, uygun fiyatlı ve işletme dostu süreçlerin modellenmesini hedeflemektedir. Böylece süreçlerin kontrollü yürütülmesi, kurum işleyişinin standartlaştırılması ve süreçlerin eksikliklerini tespit edebilecek bir yapının oluşturulmasını sağlar [1]. BPM'de süreçlerin ortaya çıkarılması, analiz edilerek modellenmesi ve kontrol edilmesi gibi işlemler geliştirme zamanının en önemli kalemidir. BPM'nin işletmeye sunduğu faydalar arasında süreçlerin kontrol altına alınması, süreç iyileştirme işlemlerine kolaylık sağlaması, performans takibi, bilgi teknolojileri ile iş dünyası arasında iletişimi kolaylaştırması, etkinlik ve yeterlilik takibine olanak sağlaması ve işletme bünyesinde yapılan işlerin standartlaştırılması yer almaktadır. BPM stratejileri arasında sürekli süreç iyileştirme ve iş süreci yeniden mühendisliği (BPR: Business Process Reengineering) yer almaktadır. Sürekli süreç iyileştirmede mevcut süreç yapısı sorgulanmadan sorunları tanımlama, adım adım çözme ve her seferinde bir adım ve bir seferde bir düzeltme mantığı ile sürekli süreç iyileştirme yaklaşımı izlenmektedir. BPR'de ise mevcut sürecin temel varsayım ve ilkeleri sorgulanarak radikal değişiklikler sonucunda sürecin yeni baştan tasarlanması yaklaşımı dikkate alınmaktadır. Bu yaklaşımlar çerçevesinde bakım faaliyetlerinin tanımlanmas1, süreçlerin görselleştirilmesi, analiz edilmesi, yeniden tasarlanması ve uygulanarak kontrol işlemlerinin yapılması gerekmektedir.

Bakım faaliyetleri, makine ve teçhizatın istenen fonksiyonlarının en iyi şekilde ve 
beklenen düzeyde gerçekleştirilebilmesi için yapılan tamir, onarım, yağlama vb. faaliyetlerin gerçekleştirilmesini kapsar. Genel olarak bakım faaliyetleri plansız/arızi ve planlı bakım olmak üzere iki ana gruba ayrılmaktadır [3]. Plansız/arızi bakım, makine veya teçhizatın belirgin bir arızası veya duruşu gerçekleştiğinde yapılan bakım tekniğidir. Temelde "bozulana kadar çalıştırın” mantığıyla arıza meydana gelene kadar makine veya teçhizat çalıştırılmaya devam edilir. Bu yöntem; yaygın olarak, çok sayıda yedekleri bulunan ve fazla pahalı olmayan makinelerle üretim yapan tesislerde ve atölyelerde uygulanmaktadır [4]. Planlı bakım ise ölçüm tekniklerinden, istatistiki bilgilerden ve deneyimden faydalanılarak belirlenmiş plan ve programlar dahilinde yapılan bakım onarım işlemidir. Planlı bakımın amacı, makine duruşlarını azaltarak verimliliği arttırmak, makinelerin ekonomik ömürlerini uzatmak, ve bakım masraflarını azaltmaktır [3]. Planlı bakım faaliyetleri, kendi arasında üç gruba ayrılmaktadır. Bunlar periyodik/koruyucu, önleyici ve kestirimci bakımdır. Periyodik/ koruyucu bakım, makine veya ekipmanların, belirli bir program dahilinde, arıza oluşma şartı aranmadan planlı ve koordineli olarak ekipmanların kullanılabilirlik süresini arttırmaya yönelik yapılan bir bakım çeşididir [5]. Periyotlar ya satıcı firmanın ya da firmanın geçmiş bakım kayıtları ve çalışma şartlarını değerlendirmesiyle belirlediği zaman aralıklarıyla belirlenir. Önleyici bakım, ekipmanların ömrünü arttırarak optimum kullanımlarını sağlamak amacıyla test, ölçme, ayarlama, parça değiştirme gibi faaliyetlerle gerçekleştirilen planlı bir bakımdır [6]. Kestirimci bakım ise, üretim sırasında yapılan ölçümlerle makinelerin performansının izlenmesiyle ne zaman bakıma ihtiyaç olacağına karar verilerek oluşabilecek arızayı onarmak için yapılan planlı bir bakım yöntemidir [7].

İşletme yapısı, maliyet unsurları, üretim kayıpları ve işgücü planları dikkate alınarak uygun bakım planları oluşturulmalıdır. Her bakım kendince farklı alanlarda bir sonraki bakıma göre daha uygun ve karlı olabilmektedir. Örneğin; çok fazla yedeği olan ve yedek makine sayesinde kolaylıkla arıza etkisi elimine edilebilen küçük işletmelerde arızi bakım tercih edilebilir. Çünkü diğer bakım faaliyetleri daha fazla maliyet unsuru içermekte ve daha fazla zaman gerektirmektedir. Ancak üretimde kritik bir rol oynayan ve yatırım maliyeti yüksek ayrıca; arıza zamanları tespit edilebilecek düzeyde ise burada arızi bakım yerine kestirimci, periyodik/koruyucu veya önleyici bakım faaliyetlerinden en uygun olanı tercih edilmelidir. Günümüz işletmelerinde karma bakım faaliyetleri uygulamasının yapıldığı görülmektedir. Yani üretim sistemi doğru bir şekilde incelenerek en uygun bakım faaliyeti en uygun makineye uygulanmaktadır.

Bakım faaliyetlerinin yönetimi, planlanması ve izlenmesinde kolaylık ve etkinlik sağlamak amacıyla bakım yönetim sistemi oluşturulup, işlemler daha kısa sürede ve daha doğru bir şekilde yapılabilmektedir. Piyasada bunun için hazırlanmış farklı özellik ve nitelikte karar destek sistemleri ve kurumsal kaynak planlama (ERP: Enterprise Resource Planning) yazılımları mevcuttur. ERP yazılımlarında yer alan bakım yönetimi modülleri, genel olarak üretim esnasında kullanılan makine ve teçhizatın durmasına 
neden olabilecek beklenmedik arızaları en alt düzeye indirmek için sistematik olarak bakım planlarını oluşturarak, gerekli planlı ve önleyici bakımların organize edilmesini sağlar. Bu yazılımlar sayesinde maliyetlerin takibi sağlanabilmekte ve gereken durumlarda müdahale edilerek maliyetleri azaltabilmek için yapılması gerekenler belirlenip uygulanabilmektedir. Sonuç itibariyle bakıma gereken önem verilip plan ve programların firmaya uygun bir yazılım ile desteklenmesiyle üretim akışı, kalite, zaman, maliyet ve verimlilik üzerinde oluşabilecek olumsuz etkilerin azaltılması ve fayda maksimizasyonu sağlanabilmektedir.

Bakım planlaması faaliyetlerine ilişkin ilgili literatür incelendiğinde çalışmaların genellikle operasyonel seviyedeki problemlerle ilgilendiği görülmektedir. Örneğin Gürbüz ve Cömert [8], çalışmalarında uçakların fabrika seviyesindeki bakım planlaması için tam sayılı doğrusal programlama kullanarak bir bakım planlama modeli oluşturmuştur. Karaoğlan ve arkadaşları [9] tam zamanında üretim sistemi uygulamalarında bakım politikalarının önemini incelemiştir. Görener [10], bulanık ortam koşullarında bakım stratejisi seçimi için çok kriterli seçim yöntemlerinin faydalanmıştır. Uzun ve Özdoğan [6] ekipmanların optimum bakım zamanlarının belirlenmesi ve bakım maliyetlerine dayanarak bakım modelinin seçimi için güvenirlik analizine dayalı önleyici bakım planlama çalışması gerçekleştirmiştir. Anagün ve Soy [11] ve Baraçlı ve arkadaşları [12] çalışmalarında Toplam Verimli Bakım (TVB) geçiş sürecinde başarılı olmayı hedefleyen firmalar için yol haritaları belirlemişlerdir. Bakım yönetimi konusunda gerçekleştirilen detaylı literatür taramaları [13], Garg ve Deshmukh [14] ve Parida ve arkadaşları [15] tarafindan gerçekleştirilmiştir.

Şahin [16] bilgisayar destekli bakım yönetim sistemlerinin tasarlanmasına yönelik olarak çalışmalar gerçekleştirmiş ve havacılık sektöründe uygulama yapmıştır. Er [7] bilgisayar destekli bakım yönetim sistemlerini ve bu sistemlerin Türkiye'deki uygulama düzeyini incelemiştir. Türkan ve Esnaf [17] bilgisayar destekli bakım yönetim çatısının oluşturulmasına yönelik bir uygulama gerçekleştirmiştir. Akasah ve arkadaşları [18] çalışmalarında IDEF0 diyagramlarını kullanarak okullar için bakım yönetim sistemi modeli tasarımı gerçekleştirmiştir. Qing [19], trenlere bakım hizmeti veren bir firma için bakım yönetim bilgi sistemi tasarımı gerçekleştirmiştir. Bilgisayar destekli bakım yönetimi sistemlerine yönelik detaylı literatür taraması Kans [20] tarafından yapılan çalışmada yer almaktadır. Literatürde sadece Pai ve Rane [21] tarafından gerçekleştirilen çalışmada, ERP yazılımına entegre bakım modülü tasarımını nükleer santral özelinde gerçekleştirmiştir. Castillo-Martinez ve arkadaşları [22] ISO standartlarına dayalı bakım yönetim sistemlerinin temel unsurlarını tanımlayan kavramsal şemalar ile yazılım geliştirmişler ve gerçek bir uygulama üzerinden yazılımı test etme işlemini gerçekleştirmişlerdir.

$\mathrm{Bu}$ çalışmada iş süreç yönetimi ve iş süreç yeniden mühendisliği gereği mevcut durumda manuel olarak yürütülen bakım süreçlerinin bilgi teknolojileri ile desteklene- 
rek yeniden tasarlanması sonucu kalite, zaman ve maliyet kayıplarının engellenmesi amaçlanmıştır. Aynı zamanda bakıma gereken önemin verilmesi ve bakım faaliyetleri sonuçlarının izlenebilmesini sağlıklı bir şekilde gerçekleştirmek adına bir ERP sistemi içerisinde bakım yönetim sistemi tasarlanarak iş modellemesi gerçekleştirilmiştir. Kullanıcı ve yazılımcı arasındaki iletişimi sağlamak amacıyla bakım sistemi analizlerinin ardından ara yüz tasarımında olması gereken veri girişleri, verilerin kullanım amaçları ve kullanıcı ile yazılımcının gerçekleştirmesi gereken işlemler açıklanmaya çalışılmıştır. Bakım yönetimi programında yer alacak modüller ve iş modellemeleri ayrıntılı olarak gösterilmiş ve ardından kullanıcıya yardımcı olmak ve kullanıcının gerekli bilgileri elde etmesi için raporlama modülünün iş modellemesi ile sistem tarafından hesaplanacak performans göstergeleri açıklanmıştır. Performans göstergeleri seçiminde arızalar arası geçen ortalama süre, maliyet ve planlama ile bakım başarı oranları dikkate alınmıştır. Bu performans göstergeleri sayesinde bakım planlama ekibi gerçekleştirdikleri durumlar ile yapılması gereken iyileştirmeler hakkında bilgi sahibi olacak ve sonuçta etkin bir bakımın yapılabilmesine olanak sağlanacaktır. Dolayısı ile çalışmada sunulan sistem önerisinin, bakım süreçlerini, dijitalleşme kapsamında bilişim teknolojilerine dayalı geliştirmek ve kurumsal kaynak yönetimi yazılımlarına entegre etmek amacına sahip başta imalat sektörü olmak üzere birçok kuruluş için katkı sağlayacağı düşünülmektedir. Aynı zamanda literatürden farklı olarak sektöre özgü bir modül tasarımı yapmak yerine genel bir modül tasarımı ile bakım yönetim sisteminin hem yazılımcı hem de kullanıcı bakış açısı ile nasıl modellenmesi gerektiği ve hangi verilerin kullanılarak bakım hakkında genel ve performansa dayalı sonuçların elde edilebileceği ile ilgili bilgiler sunulmuştur.

Çalışmanın ikinci bölümde, bakım yönetim sistemi açıklanmıştır. Üçüncü bölümde bakım planlama modülüne ilişkin kullanıcı ve yazılımcı tarafından yapılması gereken işlem ve süreçlerin iş modeli ve performans kriterleri tanımlanmıştır. Çalışmanın son bölümünde ise sonuç ve gelecek çalışmalara yer verilmiştir.

\section{BAKIM YÖNETIM SISTEMI}

Bakım yönetim sisteminin görevi, bakımın daha düzenli, hızlı ve güvenilir bir şekilde yapılması, maliyet, işçi performansı ve görsel dokümantasyon gibi verilere kolaylıkla ulaşılması, bakım çalışmalarının etkin yapılabilmesi amacıyla kayıt tutma ve raporlama işlerini ilgili birime elektronik ortam vasıtasıyla iletimini sağlamaktır.

Bakım yönetim sistemi, kısaca tüm bilgi ve analizleri kayıt altına alan yazılımların etkin olarak kullanılarak sistem verimliliğini ve takip edilebilirliği arttırmaktadır. Buna göre bakım yönetim sisteminde veri yönetimi, kontrol ve izleme, planlama ile maliyet bileşenlerinin yer alması gerekmektedir. Bakım veri yönetimi, sistemi oluşturacak hiyerarşik yapının oluşturulması için gerekli bilgileri içerir. Yani sistem tanımları, konumlar, ekipmanlar, parçalar gibi makine ve ekipmanların hangi birimde olduğu, 
tanımlamalarının yapıldığı ve yedek parça listelerinin yer aldığı bölümdür. Bakım kontrol izleme, arıza takibinin yapıldığg ve gerekli görülen işlerin yapılması için talimatların verildiği, ekipman duruş süreleri ile kullanılan malzeme takibi, geçmişe ait bakım kontrol izleme raporlarının yer aldığı bölümdür. Bakım kontrol izleme sayesinde fiili ve planlanan işlerin karşılaştırılması yapılmaktadır. Bakım planlama, hangi bakımın yapılacağı, bakım içeriklerinin ne olduğu, bakımın ne zaman yapılacağı ve kim tarafından yapılacağına dair bilgilerin yer aldığı bölümdür. Son olarak bakım maliyetleri ise iş plan maliyeti, bakım türü maliyeti, işçilik ve malzeme maliyetleri gibi maliyet kalemlerinin yer aldığı kısımdır. Tüm bu verileri içeren yazılımların kullanılması sonucunda işletmedeki tüm birim, makine ve yedek parçalar düzenli olarak kayıt altına alınabilecek, bakım planları etkin bir şekilde hazırlanarak incelenebilecek, bakım personelinin kontrol ve denetimi etkili olarak yapılabilecek ve geçmiş verilerle maliyetler kolaylıkla izlenerek verimlilik artışı sağlanabilecektir.

Bakım yönetim sisteminin kullanımı ile bakım maliyetlerinde \%15-\%30, yedek parça stok maliyetlerinde \% 15-20, duruş sürelerinde en az \%25 azalma, arıza sayısında $\% 40$ - \%80 arasında azalma, bakım bilgilerini izleme ve planlama yapabilme gibi faydalar yer almaktadır [23]. Bakım yönetim sistemi, ERP yazılımları içerisinde kullanılan ayrı bir modül olarak veya tek başına bakım üzerine yazılmış programlarla da yürütülebilmektedir. ERP, planlanan hedefler doğrultusunda, tedarik, üretim ve dağ1tım kaynaklarının etkin ve verimli şekilde planlanması, koordine ve kontrol edilmesi fonksiyonlarını içeren entegre yazılım paketidir [24]. Bünyesinde farklı modüller barındırarak işletme içi koordinasyonunu, yönetim ve planlama faaliyetlerini en etkin şekilde yürütür. Birçok ERP yazılımlarında bakım faaliyetlerinin yürütüldüğü bakım yönetim modülleri yer almaktadır. Bakım yönetiminin gerçekleştirebilmesi için gerekli makine parçaları tanımları ve bu parçaların zamanında temin edilmesi, maliyet kalemlerinin belirlenmesi ile personel planlaması işlemlerinin verimli ve etkin olarak gerçekleştirilmesi gerekmektedir. Dolayısıyla bakım yönetimi modülü ERP yazılımlarında yer alan malzeme yönetimi, maliyet muhasebesi yönetimi, insan kaynakları yönetimi ve stok yönetimi modülleriyle de yakından ilişkilidir.

\section{BAKIM YÖNETIMI PROGRAMININ MODELLENMESI}

Çalışma kapsamında bakım yönetimi programı tasarımı, bir yazılım firması ile birlikte çalışılarak bakım yönetim modülü içeren ERP programlarının incelenmesi ile gerçekleştirildikten sonra IBM Business Process Manager programı kullanılarak İş Süreç Yönetimi Simgeleri (BPMN: Business Process Management Notation) mantığıyla modellenmiştir. Buna göre bakım yönetimi programında olması gereken modüller; Bakım Bilgileri Tanımlama, Bakım Detayı Tanımlama, Bakım Makine İlişkilendirme, Bakım İş Emri Tanımlama, Bakım İş Emri Kapama ve Raporlama olarak tanımlanmıştır. Ancak burada uygun veri giriş ve kontroller oluşturularak sadece bakım ile ilgili alanların iş modellemesi gerçekleştirilmiştir. 


\begin{tabular}{|c|c|c|c|c|c|}
\hline \begin{tabular}{|l} 
Sistem \\
islemi/görevi
\end{tabular} & 画 & $\begin{array}{l}\text { Başlangıç } \\
\text { Olayı }\end{array}$ & & Basit karar & \\
\hline $\begin{array}{l}\text { Kullanıcı } \\
\text { ișlemi/görevi }\end{array}$ & తి & Bitiş Olay1 & & $\begin{array}{l}\text { Coktan seçmeli } \\
\text { karar/Disllamalı } \\
\text { VEYA Geçidi }\end{array}$ & \\
\hline Alt süreç & 8 & Açklama & & $\begin{array}{l}\text { Dahil çoktan } \\
\text { seçmeli } \\
\text { karar/ççsel } \\
\text { VEYA Geçidi }\end{array}$ & \\
\hline Veritabanı & (10) & Veri Değeri & . & $\begin{array}{l}\text { Paralel karar/VE } \\
\text { Gecidi }\end{array}$ & \\
\hline
\end{tabular}

Buna göre sırasıyla modüllerin iş modelleri ve model tanımları açıklanmıştır. Ayrıca ara yüzde kullanıcı tarafından girilen veya sistem tarafindan kayıtlı verilerden kullanıcının açılan listeden (comboboxtan) seçmesi gereken veri tanımlamaları ve açıklamaları yer almaktadır. Çalışma kapsamında kullanılan iş süreci modelleme simgelerinin bazıları kısaca Şekil 1'de gösterilmiştir.

\subsection{Bakım Bilgileri Giriş Ekranı}

Bakım Bilgileri Giriş Ekranı, Şekil 2'de gösterildiği gibi Bakım Bilgileri Girişi ve Kayıt işlemlerini içermektedir.

Bakım Bilgileri Giriş Ekranı, bakımın tanım tablosunda olması gereken bakım kodu-

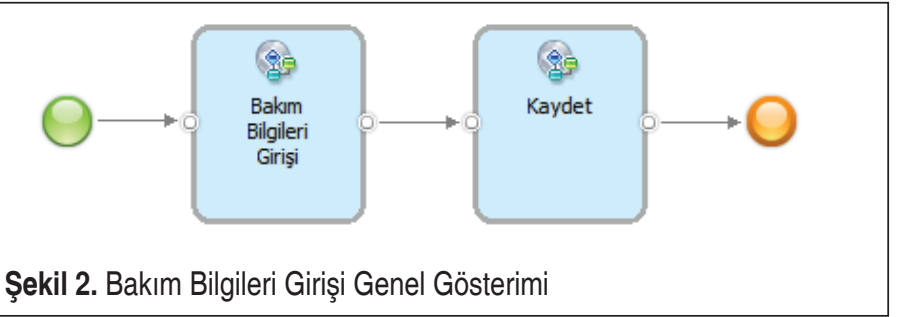

nun, tipinin ve bakımı gerçekleştirecek olana göre gerekli veri girişlerinin yapıldığ 1 ekrandır. Bakım Bilgileri Girişi iş modelinde veri girişlerinin yer aldığ 1 model Şekil 3 'te yer almaktadir.

Şekil 3 'te yer alan veri giriş alanları Tablo 1'de yer almaktadır.

Şekil 4'te Bakım Bilgileri Girişi Kontrolü ve Bakım Bilgileri Girişi Güncelleme Kontrolü sonrası, kaydın uygunluğu çerçevesinde veri tabanına kayıt işlemi ya da hatalı girişlere yönelik uyarı verme durumları gerçekleşecektir. Kaydet sürecinin genel gösterimi diğer modüllerdeki giriş ve güncelleme işlemlerinde de benzerdir. 


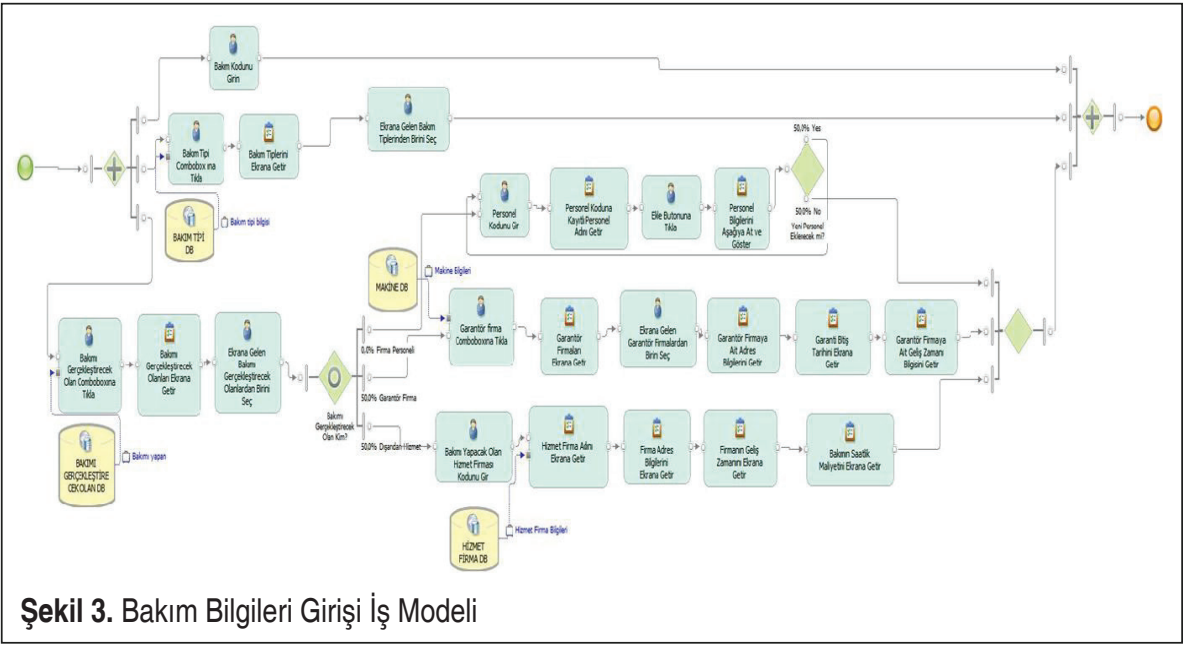

Tablo 1. Bakım Bilgileri Girişindeki Veri Giriş Alanları

\begin{tabular}{|l|l|}
\hline Veri Giriş Alanı & Açıklama \\
\hline Yedek Parça Değişimi & $\begin{array}{l}\text { Yedek Parça Değişimi: Bakım esnasında makine ürün ağacında yer alan } \\
\text { yedek parçaların değişimi söz konusu ise kullanıcı bu bölümü işaretlemeli- } \\
\text { dir. }\end{array}$ \\
\hline $\begin{array}{l}\text { Planlanan Bakım } \\
\text { Süresi }\end{array}$ & $\begin{array}{l}\text { Planlanan Bakım Süresi: Bakımın tahmini olarak ne kadar sürede gerçek- } \\
\text { leştirileceği bilgisini içermektedir. Bu sayede planlanan bakım süresi ile } \\
\text { gerçekleşen bakım süresinin karşılaştırılmasına olanak sağlanacaktır. }\end{array}$ \\
\hline Bakım Periyodu & $\begin{array}{l}\text { Bakım Periyodu: Bakım tipi duruşlu veya duruşsuz periyodik bakım olarak } \\
\text { seçilmişse bakımın ne kadar süre aralıklarla tekrarlanması gerektiği konu- } \\
\text { sunda bilginin elde edilmesini sağlayacaktır. }\end{array}$ \\
\hline Ölçüm Durumu & $\begin{array}{l}\text { Öıçüm Durumu: Bakım tipinin duruşlu veya duruşsuz kestirimci bakım } \\
\text { olması durumunda makine özelliklerine uygun ölçüm durumları belirlenir. } \\
\text { Öıçüm durumuna uygun ölçüm değeri en yüksek ve en düşük ölçüm değer- } \\
\text { leri arasında olmalıdır. Aksi takdirde makine bakıma alınmalı ve kontrolleri } \\
\text { gerçekleştirilmelidir. }\end{array}$ \\
\hline Bakım İçeriği Açıklama & $\begin{array}{l}\text { Bakım İçeriği Açıklama: Bakım esnasında yapılacak işlemler ve öncelik- } \\
\text { lerinin yanı sıra kullanılacak malzemeler ve personele bildirilmesi gerekli } \\
\text { önemli bilgiler yer alabilmektedir. }\end{array}$ \\
\hline
\end{tabular}

Bakım Bilgileri Giriş Kontrolü modeli Şekil 5’te gösterilmektedir. Buradaki kontroller sistem tarafından gerçekleştirilmekte olup bakım kodu bilgisi, karakter sayısı ve benzer kayıt kontrolleri yapılmaktadır. Ayrıca bakım tipi ve bakımı gerçekleştirecek olan bilgisinin boş bırakılmaması gerektiğinden veri giriş kontrolünden geçirilmektedir. Bakımı gerçekleştirecek olan bilgisindeki kararlar sayesinde seçimler denetlen- 

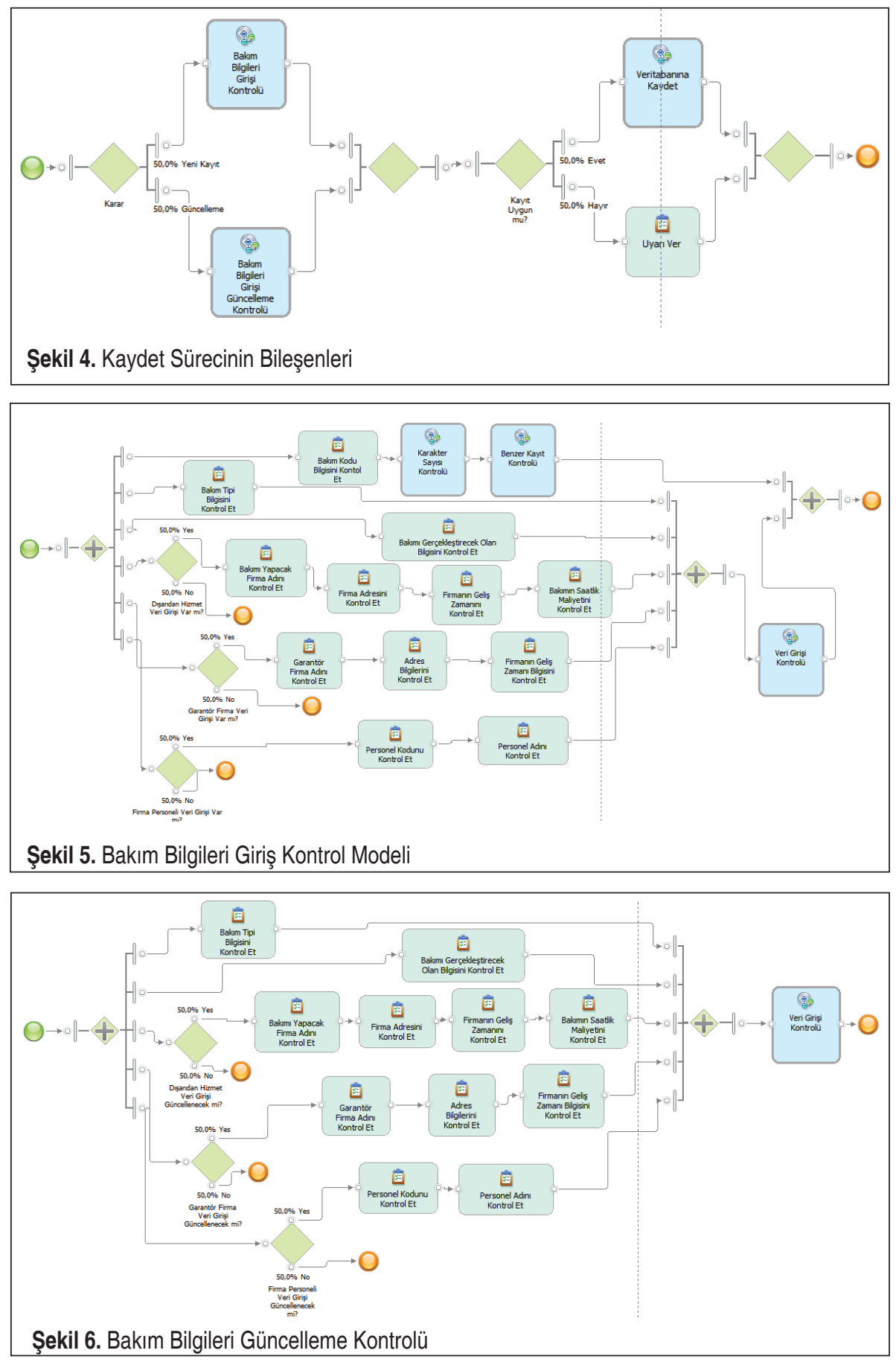
mekte ve her bir seçime uygun veri girişlerinin yapılıp yapılmadığına dair veri giriş kontrolleri yapılmaktadır.

Gerekli kontrollerin ardından veriler istenen şekilde girilmediyse ya da veri girişleri eksikse sistem tarafından kullanıcıya gerekli uyarılar yapılmaktadır. Bakım Bilgileri Girişi Güncelleme Kontrolünde kodun güncellenmesine izin verilmediğinden kod dışındaki Bakım Bilgileri Giriş Kontrolünde yer alan diğer kontroller gerçekleştirilir. Şekil 6'da Bakım Bilgileri Güncelleme Kontrolü yer almaktadır.

Tüm kontrollerin tamamlanmasının ardından kontrol sonuçları olumlu ise veri tabanına kayıt işlemi gerçekleştirilir. Sonuç olarak bakım bilgileri giriş modülü tamamlanmış olmaktadır. Bakım bilgileri güncelleme ekranında bakım kodu dışındaki veriler güncellenebilmektedir.

\subsection{Bakım Detayı Giriş Ekranı}

Bakım Detayı Giriş Ekranı, bakım kodunun seçimi sonrası sistem tarafından bakım tipi bilgisinin getirildiği, ardından da bakımın içeriğinin açıklandığ 1 yedek parça değişiminin yapılıp yapılmadığı ve bakım tipine uygun gerekli verilerin girildiği ekrandır. Veri girişi yapılacak tanımlamalar ve açıklamaları Tablo 2'de yer almaktadır.

Tablo 2. Bakım Detayı Girişindeki Veri Giriş Alanları

\begin{tabular}{|l|l|}
\hline Veri Giriş Alanı & Açıklama \\
\hline Yedek Parça Değişimi & $\begin{array}{l}\text { Yedek Parça Değişimi: Bakım esnasında makine ürün ağacında yer alan } \\
\text { yedek parçaların değişimi söz konusu ise kullanıcı bu bölümü işaretleme- } \\
\text { lidir. }\end{array}$ \\
\hline $\begin{array}{l}\text { Planlanan Bakım } \\
\text { Süresi }\end{array}$ & $\begin{array}{l}\text { Planlanan Bakım Süresi: Bakımın tahmini olarak ne kadar sürede gerçek- } \\
\text { leştirileceği bilgisini içermektedir. Bu sayede planlanan bakım süresi ile } \\
\text { gerçekleşen bakım süresinin karşıllaşıııımasına olanak sağlanacaktır. }\end{array}$ \\
\hline Bakım Periyodu & $\begin{array}{l}\text { Bakım Periyodu: Bakım tipi duruşlu veya duruşsuz periyodik bakım olarak } \\
\text { seçilmişse bakımın ne kadar süre aralıklarla tekrarlanması gerektiği konu- } \\
\text { sunda bilginin elde edilmesini sağlayacaktır. }\end{array}$ \\
\hline Öıçüm Durumu & $\begin{array}{l}\text { Ölçüm Durumu: Bakım tipinin duruşlu veya duruşsuz kestirimci bakım } \\
\text { olması durumunda makine özelliklerine uygun ölçüm durumları belirlenir. } \\
\text { Ölçüm durumuna uygun ölçüm değeri en yüksek ve en düşük ölçüm değer- } \\
\text { leri arasında olmalıdır. Aksi takdirde makine bakıma alınmalı ve kontrolleri } \\
\text { gerçekleştirilmelidir. }\end{array}$ \\
\hline Bakım İçeriği Açıklama & $\begin{array}{l}\text { Bakım İçeriği Açıklama: Bakım esnasında yapılacak işlemler ve öncelik- } \\
\text { lerinin yanı sıra kullanılacak malzemeler ve personele bildirilmesi gerekli } \\
\text { önemli bilgiler yer alabilmektedir. }\end{array}$ \\
\hline
\end{tabular}


Bakım Detayı Giriş Ekranı; Bakım Detayı Giriş ve Kayıt işlemlerini içermektedir. Bakım Detayı Girişi modeli Şekil 7'de gösterilmektedir. Bakım detayı girişinde öncelikle bakım kodu girilir ardından sistem tarafından koda ait bakım tipi bilgisi ekrana gelir. Bakım tiplerine göre farklı veri girişleri yapılmaktadır. Ancak planlanan bakım süresi her bakım tipi için ortak olarak doldurulması gerekli bir alandır. Yani hangi bakım tipi olursa olsun her biri için planlanan bakım süresinin doldurulması zorunlu bir alandır. Eğer bakım tipi olarak duruşlu veya duruşsuz periyodik bakım seçilmiş ise bakım periyodu bilgisi doldurulması zorunlu bir alandır. Bakım tipi olarak duruşlu veya duruşsuz kestirimci bakım seçilmiş ise ölçüm durumu, en düşük ve en yüksek ölçüm değerleri sisteme girilmelidir. Bakım esnasında yedek parça değişimi gerçekleşecek ise yedek parça değişimi kutucuğu doldurulmalıdır. Son olarak da bakım içeriği
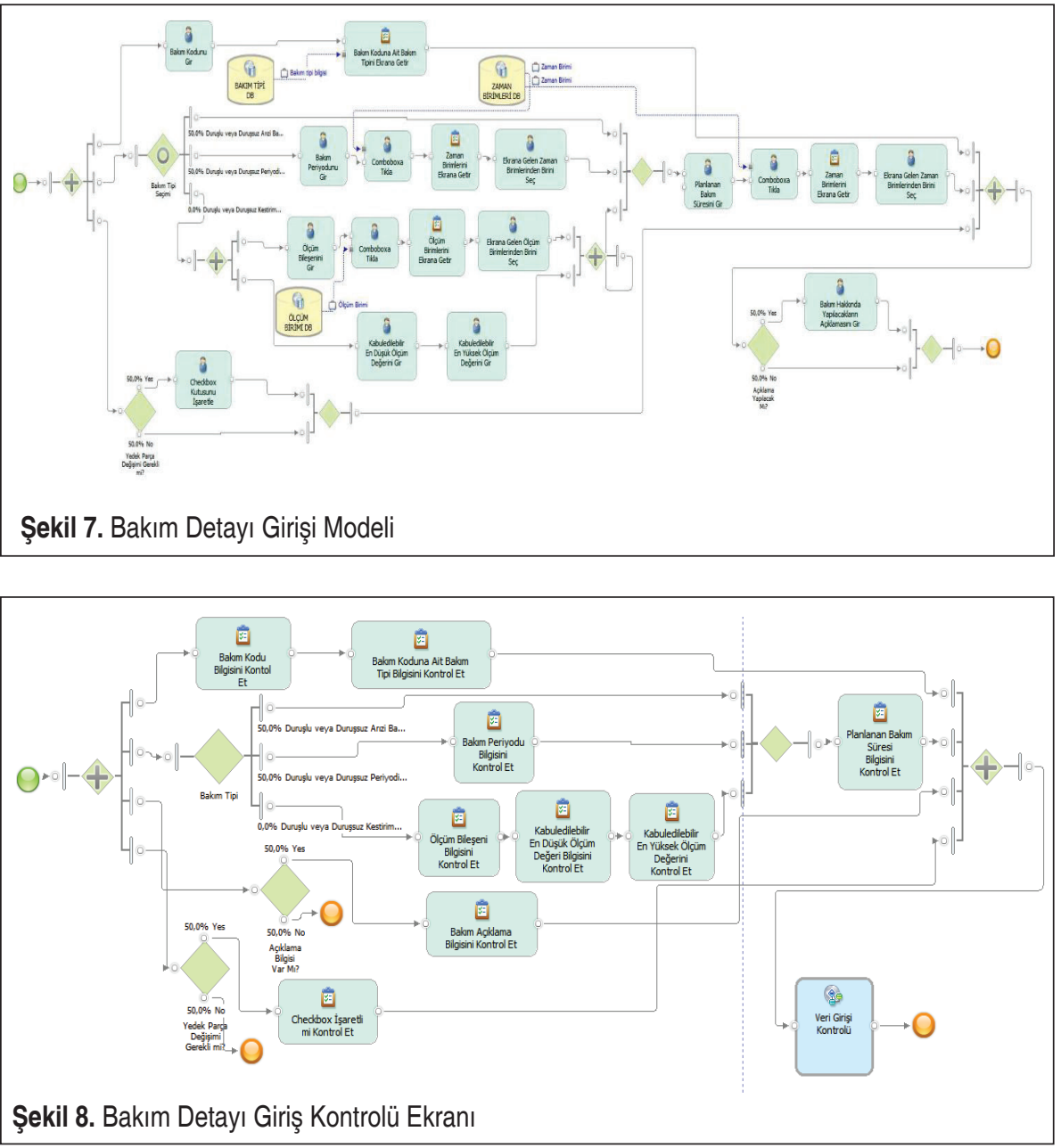


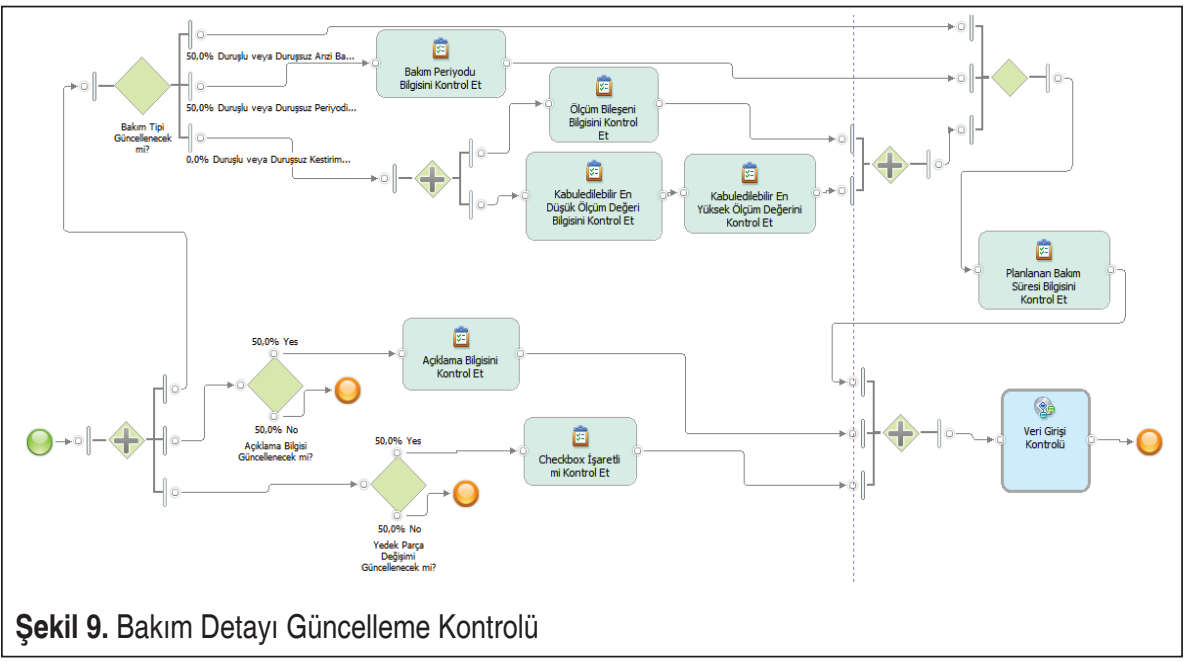

ve verilmesi gerekli bilgileri için açıklama kısmı doldurulmalıdır. Ancak bu alan doldurulması zorunlu bir alan değildir.

Kayıt ekranının ana modeli Şekil 4'te olduğu gibi bakım detayı giriş kontrolü, bakım detayı giriş güncelleme kontrolü ve veri tabanı kaydı alt modüllerini içermektedir. Buna göre öncelikle yeni bir kayıt mı yoksa kaydın güncellenmesi işleminin mi yapılacağı kararının belirlenmesinin ardından bakım detayı giriş ya da bakım detayı güncelleme kontrolleri gerçekleştirilmektedir. Kaydın uygunluğunda bir sorun yok ise veri tabanına kayıt işlemi yapılmaktadır aksi takdirde sistem tarafından uyarı verilmektedir.

Bakım detayı giriş kontrolü işlemi Şekil 8'de gösterilmektedir. Burada gerçekleştirilen kontrol veri girişlerinin eksiksiz yapılıp yapılmadığına dairdir. Şekil 9'da ise bakım detayı güncelleme kontrolü yer almaktadır. Güncelleme kısımlarında kod d1şındaki bilgiler güncellenebilmektedir. Kodların güncellemesinin yapılamamasının sebebi sistemin kodlar üzerinden işlem yapması ve dolayısıyla yapılacak en ufak değişiklerde sistem veri tabanında hatalara neden olmasıdır. Dolayısıyla kod güncelleme yerine yeni kayıt açma ya da iş emrinin açılmaması gibi yöntemler uygulanmalıdır. Bakım Detayı modülünün son adımı olan veri tabanına kayıt işlemidir.

\subsection{Makine Bakım İlişkilendirme Giriș Ekranı}

$\mathrm{Bu}$ ekran bakım ile bakımı gerçekleştirilecek makinenin ilişkilendirilmesi sonucu gerekli bilgi girişlerinin yapıldığı ekrandır. Veri giriş tanımlamaları ve açıklamaları Tablo 3 'te yer almaktadır. 
Tablo 3. Makine Bakım Ilişkilendirme Girişindeki Veri Giriş Alanları

\begin{tabular}{|l|l|}
\hline Veri Giriş Alanı & Açıklama \\
\hline Makine Kodu & Bakımın ilişkilendirileceği kayıtlı makine bilgilerinin kayıtı olduğu koddur. \\
\hline Makine Adı & Makinenin tanımını açıklayan isimdir. \\
\hline Önem Derecesi & $\begin{array}{l}\text { Makinenin firma tarafından önem derecesini göstermektedir. 1 değeri } \\
\text { makinenin kritik bir makine olduğunu ve yüksek öneme sahip olduğunu, } \\
\text { gorta derecede önemli olduğunu, 3 ise düşük bir öneme sahip olduğunu } \\
\text { göstermektedir. }\end{array}$ \\
\hline Makine Fotoğrafı & Makine koduna ait makinenin şekilsel gösterimini sağlayan fotoğraftır. \\
\hline Yedek Parça Kodu & Makine koduna ait yedek parça bilgilerinin yer aldığı kod dizinidir. \\
\hline Yedek Parça Tanımı: & Yedek parçanın ne olduğunu açıklayan tanımdır. \\
\hline Alternatifi & Yedek parçanın yerine kullanılabilecek alternatif yedek parça kodudur. \\
\hline Üretici Firma Adı ve & $\begin{array}{l}\text { Yedek parça tedarikini gerçekleştirildiği firma adı ve adres bilgilerini içer- } \\
\text { mektedir. }\end{array}$ \\
\hline Adresi & $\begin{array}{l}\text { Yedek parçanın siparişinin ardından ne kadar sürede firmaya gönderildiğini } \\
\text { belirten süredir. }\end{array}$ \\
\hline Tedarik süresi & $\begin{array}{l}\text { Makinedeki yedek parçanın makine için önem derecesini belirtmektedir. } \\
\text { Makine önem derecesindeki gibi bir ölçek kullanıımaktadır. }\end{array}$ \\
\hline Önem Derecesi & $\begin{array}{l}\text { Makinede yer alan yedek parça miktarını göstermektedir. Bu bilgi ürün } \\
\text { ağacı veri tabanında yer almaktadır. }\end{array}$ \\
\hline Kullanılan Adet & Yedek parça maliyetini göstermektedir. \\
\hline Maliyeti & Yedek parçanın şekilsel gösterimidir. \\
\hline Yedek Parça Fotoğrafı & \\
\hline
\end{tabular}

Makine Bakım İlişkilendirme Giriş Ekranı; Makine Bakım İlişkilendirme Girişi ve Makine Bakım İlişkilendirme Kayıt alt süreçlerini içermektedir. Makine Bakım İlişkilendirme Girişi ekranında ilişkilendirilecek bakım kodu seçimiyle sistem tarafından bakım koduna ait bakım tipi bilgisinin gelmesinin ardından ilişkilendirilecek makine kodu girilir. Sistem, veri tabanında kayıtlı makine koduna ait makine adını, önem derecesi ve koda ait makine fotoğrafını ekrana getirir. Bakım Detayı Ekranında yedek parça değişimi onay kutusu (checkbox) işaretlenmiş ise makine koduna ait yedek parça kodlarından değişimi yapılacak yedek parça kodu seçilir. Sistem, koda ait yedek parça tanımı, alternatifi, üretici firma adı ve adresi, tedarik süresi, önem derecesi, kullanılan adet miktarını, maliyetini ve son olarak da yedek parça fotoğrafı ekrana getirir. Birden fazla yedek parça değişimi söz konusu ise ekle butonuna tıklanarak aynı işlemler tekrarlanacaktır. Ardından bakım koduna ait bakım detayı ekranında yer alan bakım koduna ait detay bilgiler ekrana gelir. Eğer belirlenmiş bu bakım tipine göre 


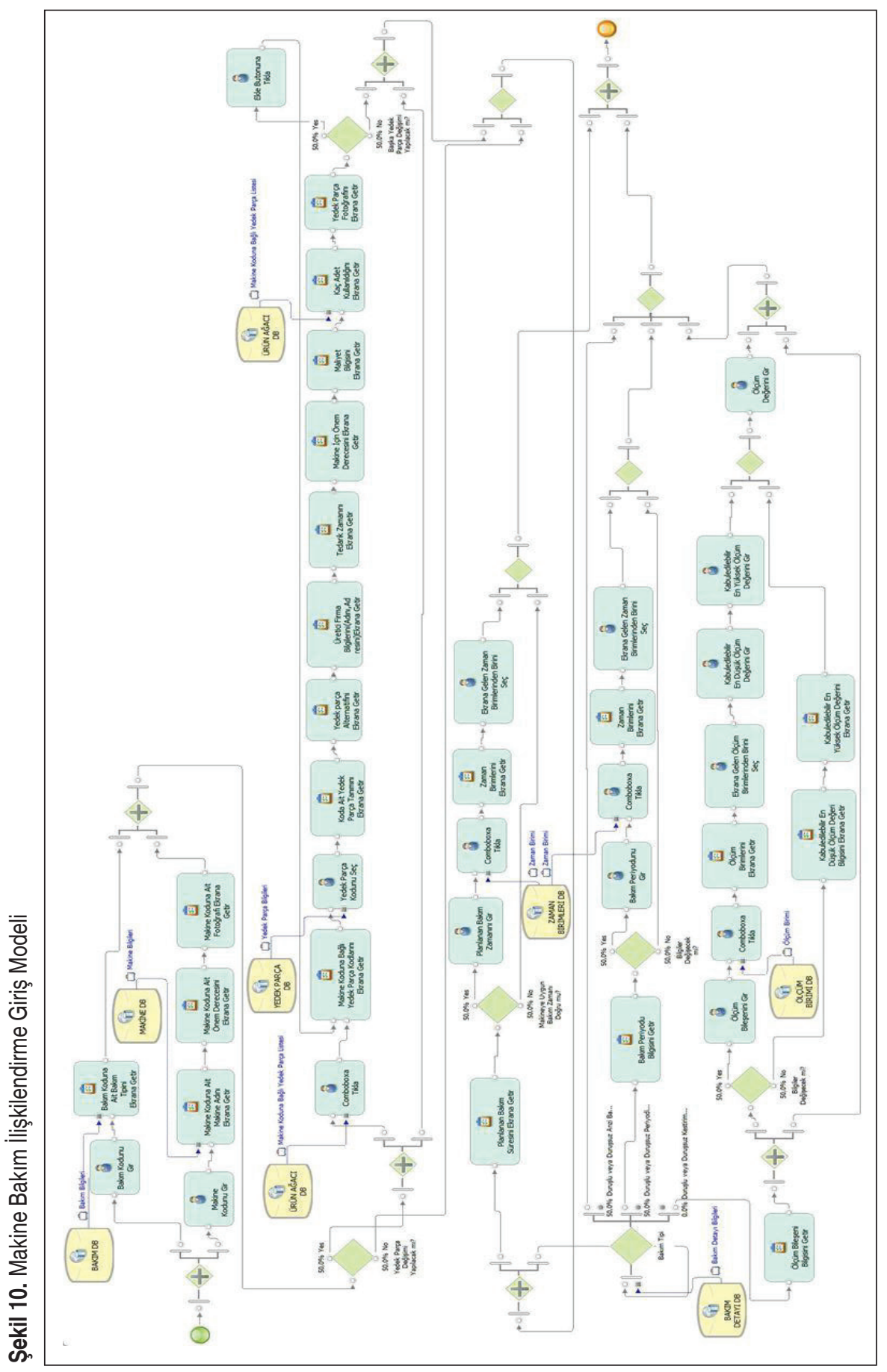


girilen veriler ve planlanan bakım zamanı makineye uygun değilse makineye uygun veriler girilerek süreç sona ermiş olur. Makine Bakım İlişkilendirme Giriş Modeli Şekil 10'da yer almaktadır.

Sürecin ikinci aşaması olan kayıt modeli; makine bakım ilişkilendirme giriş kontrolü, makine bakım güncelleme kontrolü ve makine bakım ilişkilendirme veri tabanı kaydı alt süreçlerinden oluşmaktadır. Kontrollerin gerçekleştirilmesinin ardından kaydın uygunluğu incelenir uygunluk sağlanamazsa sistem tarafından uyarı verilir. Makine bakım ilişkilendirme giriş kontrolü Şekil 11'de, makine bakım ilişkilendirme güncelleme kontrolü ise Şekil 12'de gösterilmektedir. Son olarak makine bakım ilişkilendirme veri tabanı kaydı yer almaktadır.
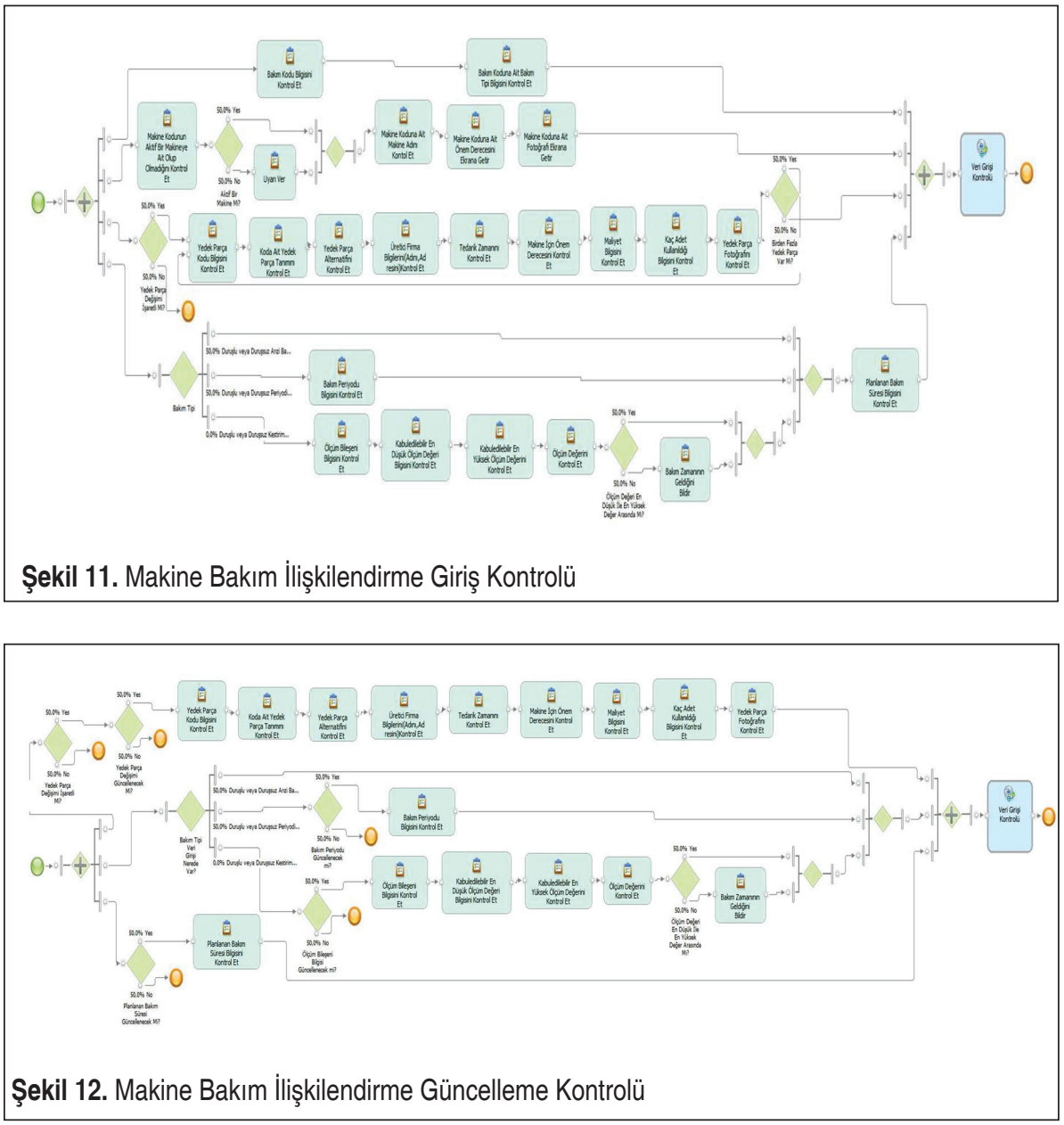


\section{4 İş Emri Giriş Ekranı}

Planlanan bakımın gerçekleştirilmesini sağlamak amacıyla makine bakım ilişkilendirmenin ardından iş emirlerinin oluşturulması gerekmektedir. Bu ekran iş emirlerinin tanımlandığı ve emirlerin verildiği ekrandır. Veri girişlerindeki tanımlamalar ve açıklamaları Tablo 4'te yer almaktadır.

İş Emri Giriş Ekranı; İş Emri Girişi ve İş Emri Kayıt alt süreçlerini içermektedir. Şekil 13 'te iş emri giriş modeli yer almaktadır. Modele göre öncelikle iş emri kod girişi yapılır. Bakım emri verilecek bakım kodu girildikten sonra sistem bakım tipini ve bakıma ait makine kodlarını getirir, kullanıcı bakıma ait makine kodunu girer. Ardından bakım başlangıç tarihi ve saati bilgileri girilir. Bakım öncelik derecesi de girildikten sonra istenirse iş emri hakkında açıklama yapılabilmektedir.

Kayıt aşaması da diğer kayıtlarda yer alan kontrol ve veri tabanı kayıt işlemlerini içermektedir.

Tablo 4. İ̧ Emri Girişindeki Veri Giriş Alanları

\begin{tabular}{|l|l|}
\hline Veri Giriş Alanı & Açıklama \\
\hline İş Emri Kodu & $\begin{array}{l}\text { Bakım emrinin verilmesinde bilgilerin depolandığı koddur. Bu kod ile iş } \\
\text { emri yürütülecek ve en sonunda da bakımın tamamlanmasının ardından } \\
\text { iş emri kapanacaktır. }\end{array}$ \\
\hline Bakım Başlangıç Tarihi & Bakımın iş emrinin verildiği yani bakımın gerçekleşme tarihidir. \\
\hline Bakım Saati & Bakımın başlama saatidir. \\
\hline Bakım Öncelik Derecesi & $\begin{array}{l}\text { Bakımın kritikliğine göre verilen öncelik derecesidir. Öncelik skalası } \\
\text { makine ve yedek parça öncelik skalasıyla aynı şekildedir. }\end{array}$ \\
\hline
\end{tabular}

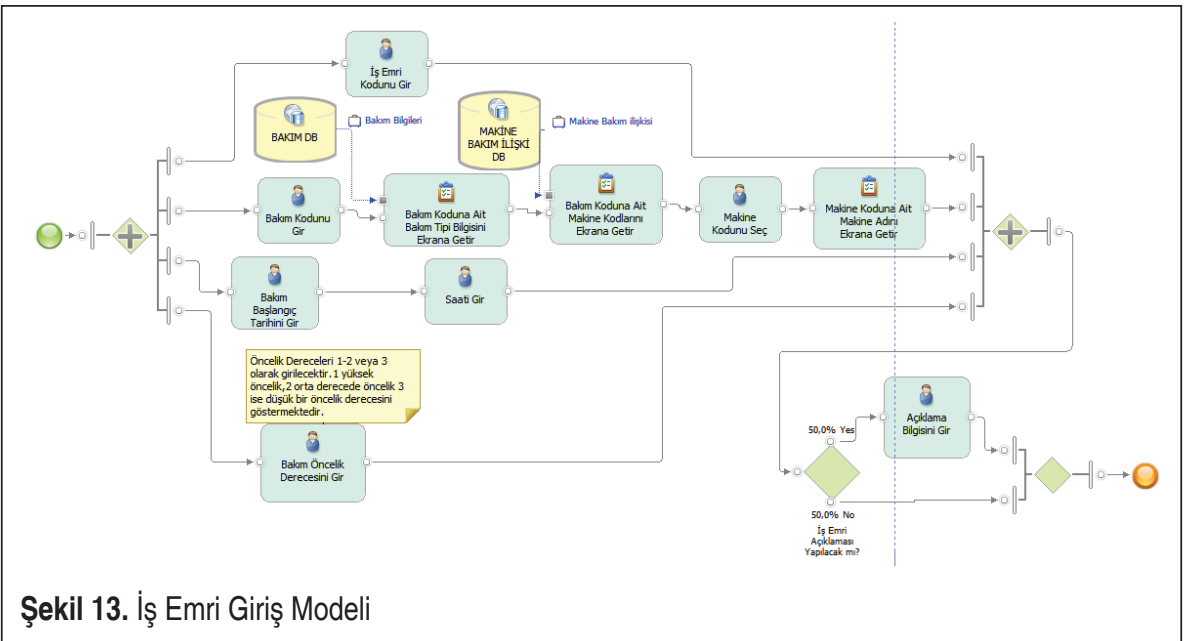




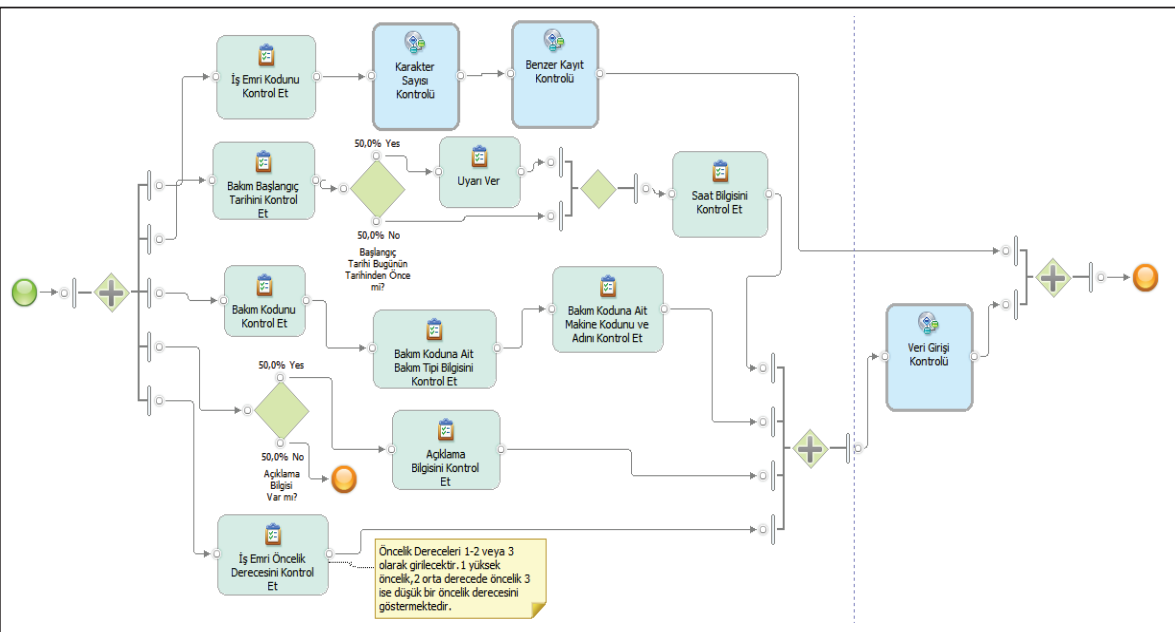

Şekil 14. İş Emri Giriş Kontrolü

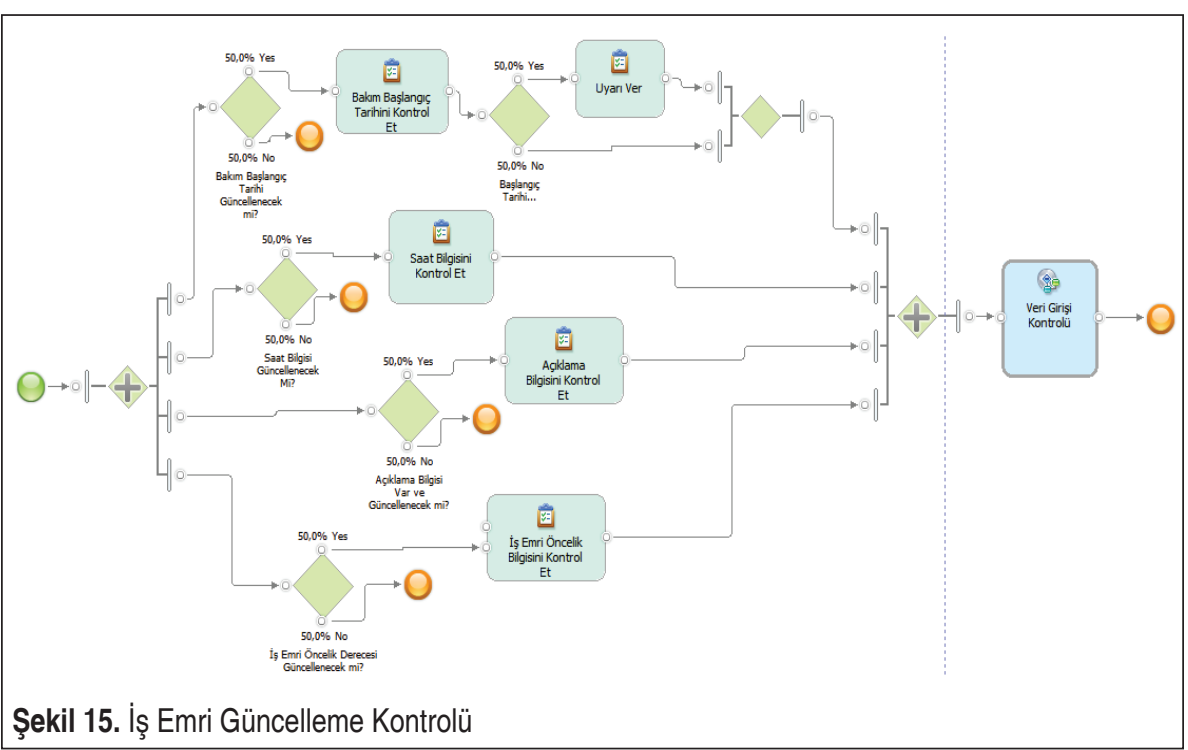

Şekil 14'te İş Emri Giriş Kontrolü modeli yer almaktadır. Burada kodun karakter sayısı ve benzer kayıt kontrollerinin yanı sıra veri girişi olması gereken ya da gerekmediği halde veri girişi yapılan kısımların boş bırakılıp bırakılmadığı kontrol edilir. Şekil 15 'te ise İş Emri Güncelleme Kontrolü gösterilmektedir. Burada da kod dişında güncellenebilecek alanlardaki veri girişlerinin yapılıp yapılmadığına dair kontroller gerçekleştirilir. Kontrollerin ardından herhangi bir hata gözlenmez ise veri tabanına ekle adlı alt model devreye girecektir. 


\section{5 İş Emri Kapama Giriş Ekranı}

İş Emri Kapama Ekranı, bakım iş emirlerinin gerçekleştirilmesinin ardından gerçekleştirilen bakım hakkında bilgilerin yer aldığı ekrandır. Veri giriş ve tanımlamaların açıklamaları Tablo 5'te yer almaktadır.

Tablo 5. İ̧ Emri Kapama Girişindeki Veri Giriş Alanları

\begin{tabular}{|l|l|}
\hline Veri Giriş Alanı & Açıklama \\
\hline Bakım Bitiş Tarihi & Bakımın sona erdiği makinenin çalışı duruma getirildiği tarihtir. \\
\hline Bakım Bitiş Saati & Bakımın saat olarak tamamlanış zamanıdır. \\
\hline $\begin{array}{l}\text { Bakımın Gerçekleşen } \\
\text { Süresi }\end{array}$ & $\begin{array}{l}\text { Bakımın, planlanan iş emirlerinin performansını ölçmek adına fiili olarak } \\
\text { gerçekleşen süresidir. }\end{array}$ \\
\hline Son Ölçüm Değeri & $\begin{array}{l}\text { Eğer ki bakım tipi kestirimci bakım ise bakımın gerçekleştirilmesinin } \\
\text { ardından son ölçüm değerinin ne olduğunu belirtir. Bu sayede bakım } \\
\text { sonrası ölçüm değerinin en düşük ve en yüksek değerler aralığında olup } \\
\text { olmadığı ve bakımın tamamlanıp tamamlanmadığının belirlenmesinde } \\
\text { kullanıcıya yardımcı olur. }\end{array}$ \\
\hline Ek Maliyet Tutarı & $\begin{array}{l}\text { Bakımı gerçekleştiren ve bakım yedek parça maliyetleri dışında meydana } \\
\text { gelebilecek durumlar sonucunda katlanııması gereken ek maliyettir. }\end{array}$ \\
\hline Açıklama & $\begin{array}{l}\text { Bakımın tamamlanmasının ardından istendiği takdirde açıklama bilgisi } \\
\text { girilebilmektedir. Burada ek maliyetlerin neler olduğu hakkında açıklama } \\
\text { yapılabilir. }\end{array}$ \\
\hline
\end{tabular}

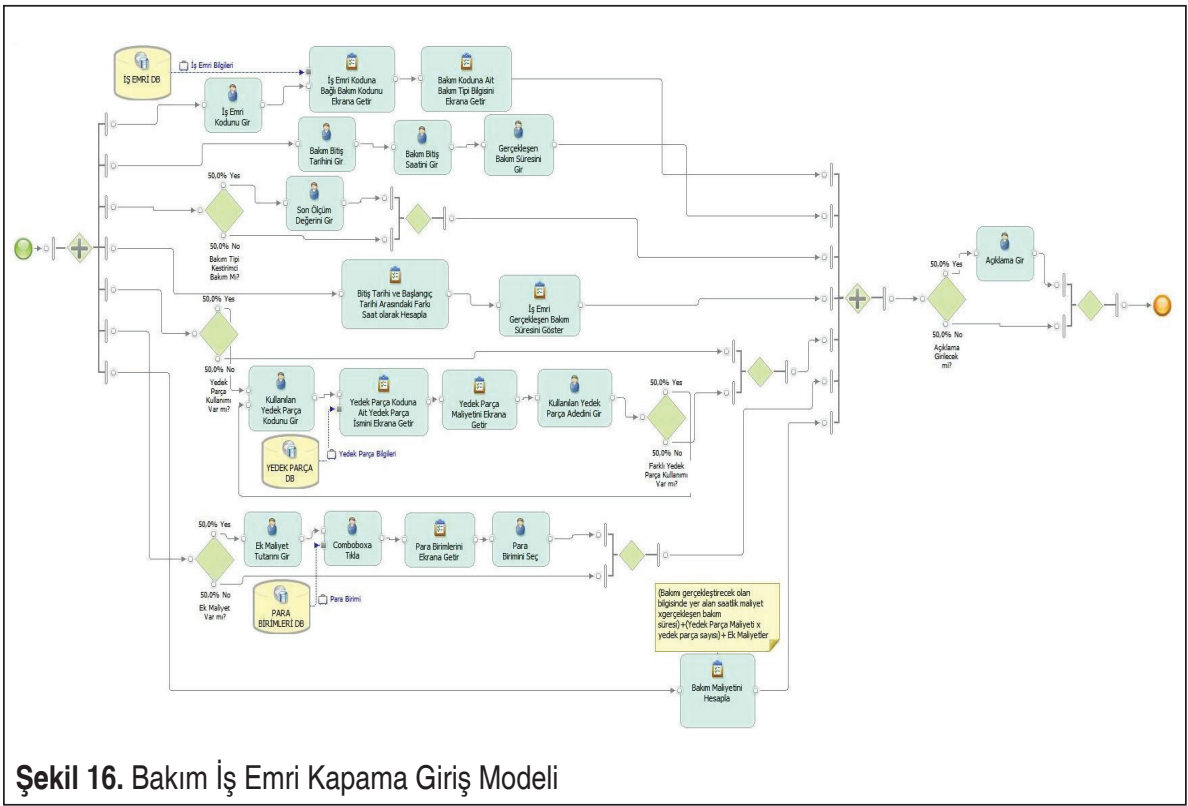


İş Emri Kapama Giriş Ekranı; Bakım İş emri Kapama Girişi ve İş Emri Kapama Kayıt alt süreçlerini içermektedir. Şekil 16'da bakım iş emri kapama giriş modeli yer almaktadır. Buna göre kişi ara yüze bakım iş emri kodu, bakım bitiş tarihi, bakım bitiş saati, gerçekleşen bakım süresi bilgilerinin girişinin ardından yedek parça kullanımı var ise yedek parça kodunu ve kullanılan yedek parça adetini girmelidir. Birden fazla yedek parça kullanımı varsa ekle butonuna tıklayarak benzer işlemler tekrarlanır. Bakım tipi kestirimci ise son ölçüm değeri bilgisi girilmelidir. Eğer ek maliyet var ise kullanıcı ek maliyet tutarını ve açıklama yapmak istiyorsa son olarak da açıklama bilgisini girmelidir.

Sistem tarafından gerçekleştirilen işlemler ise; iş emri koduna ait bakım kodu ve bakım tipi bilgilerinin ekrana getirilmesi, yedek parça kullanımı var ise yedek parça koduna ait yedek parça adı ve maliyetini ekrana getirmektir. İş emri başlangıç tarihi ile iş emri kapama bitiş tarihi arasındaki süreyi saat cinsinden hesaplayarak iş emri gerçekleşen bakım süresini göstermektedir. $\mathrm{Bu}$ da iş emirleri planlamasındaki etkinliği gösterecektir. Bakım maliyeti hesabında sistem, bakımı gerçekleştirecek olan bilgisindeki maliyet değeri ile gerçekleşen bakım süresinin çarpımı ile yedek parça maliyeti çarpı yedek parça sayısı ve son olarak da ek maliyet var ise bu üç maliyet kalemini toplayarak bakım maliyeti bilgisini sunacaktır. Kayıt aşaması da diğer kayıtlarda yer alan kontrol ve veri tabanı kayıt işlemlerini içermektedir.

Şekil 17'de bakım iş emri kapama giriş kontrolü modeli yer almaktadır. Buradaki kontroller zorunlu alanların veya zorunlu olmayan alanların veri girişleri mevcut ise veri girişi yapılıp yapılmadığına dairdir.

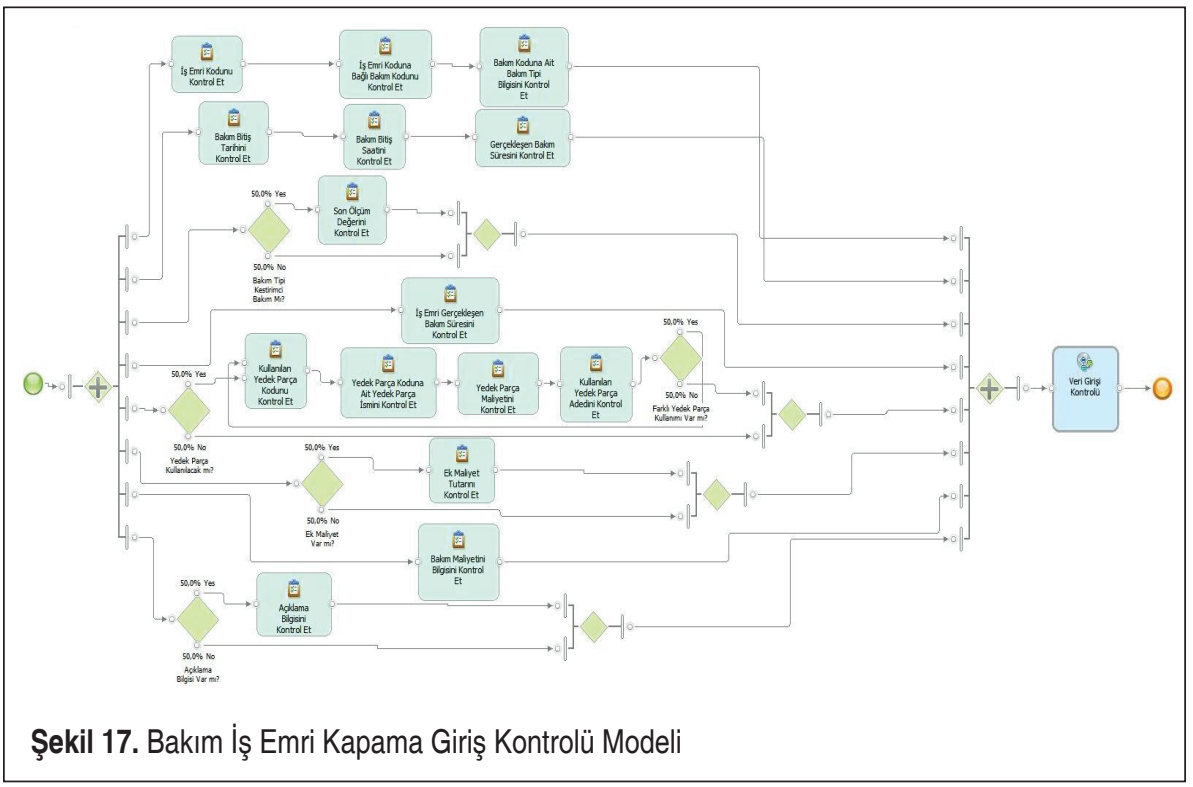




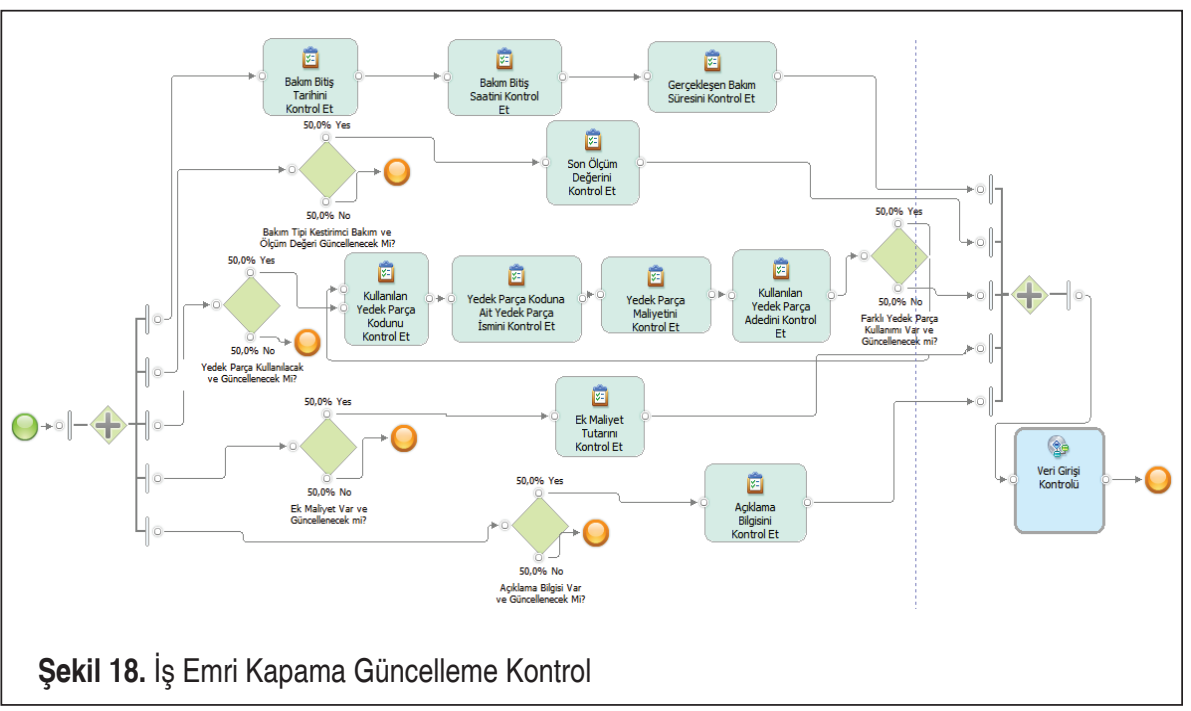

Şekil 18'de ise iş emri kapama giriş güncelleme kontrolü modelinin şekilsel gösterimi yer almaktadır. Son olarak veri tabanı kaydında da diğer kayıt süreçleriyle aynı işlemler gerçekleşmektedir.

\subsection{Raporlama}

Raporlama ekranı kullanıcı isteklerine göre istenen verilerin elde edilmesini ve bakım hakkında bilgi alınmasını sağlayan bir ara yüzdür. Buna göre kullanıcı 2 çeşit raporlama alabilmektedir. Bunlar makine bazında raporlama ve bakım tipi bazında raporlamadır. Rapor alımları belirli zaman dilimleri arasında olabileceği gibi tüm kayıtların seçimi şeklinde de gerçekleştirilebilmektedir. Bunların yanı sıra rapor ekranı, bakımın etkinliği ve faydalarının sayısal olarak ifade edilip anlaşılırlığı ve ölçümünün sağlanabilmesi adına aşağıdaki denklemlerde yer alan performans gösterge sonuçlarını da üretmektedir.

Faydalanma Oranı $=\frac{\text { Çalışma Zamanı }}{\text { Çalışma Zamanı }+ \text { Bakım Zamanı }} \times 100$

Arızalar Arası Ortalama Süre $=\frac{\text { Çalışma Zamanı }}{(\text { Arıza Sayısı } / \text { Toplam Çalışma Süresi })}$

Yedek Parça Planlama Başarı Oranı $=\frac{\text { Kullanılan Yedek Parça Miktarı }}{\text { Planlanan Yedek Parça Miktarı }}$

Planlanan İşlerin Gerçekleșme Başarı Oranı $=\frac{\text { Tamamlanan İș Emirleri Sayısı }}{\text { Planlanan İș Emri Sayısı }} \times 100$

Arıza Önleme Çalışmalarının Etkinliğ $i=\frac{\text { Toplam Bakım Süresi }- \text { Toplam Arızi Bakım Süresi }}{\text { Toplam Bakım Süresi }}$ 


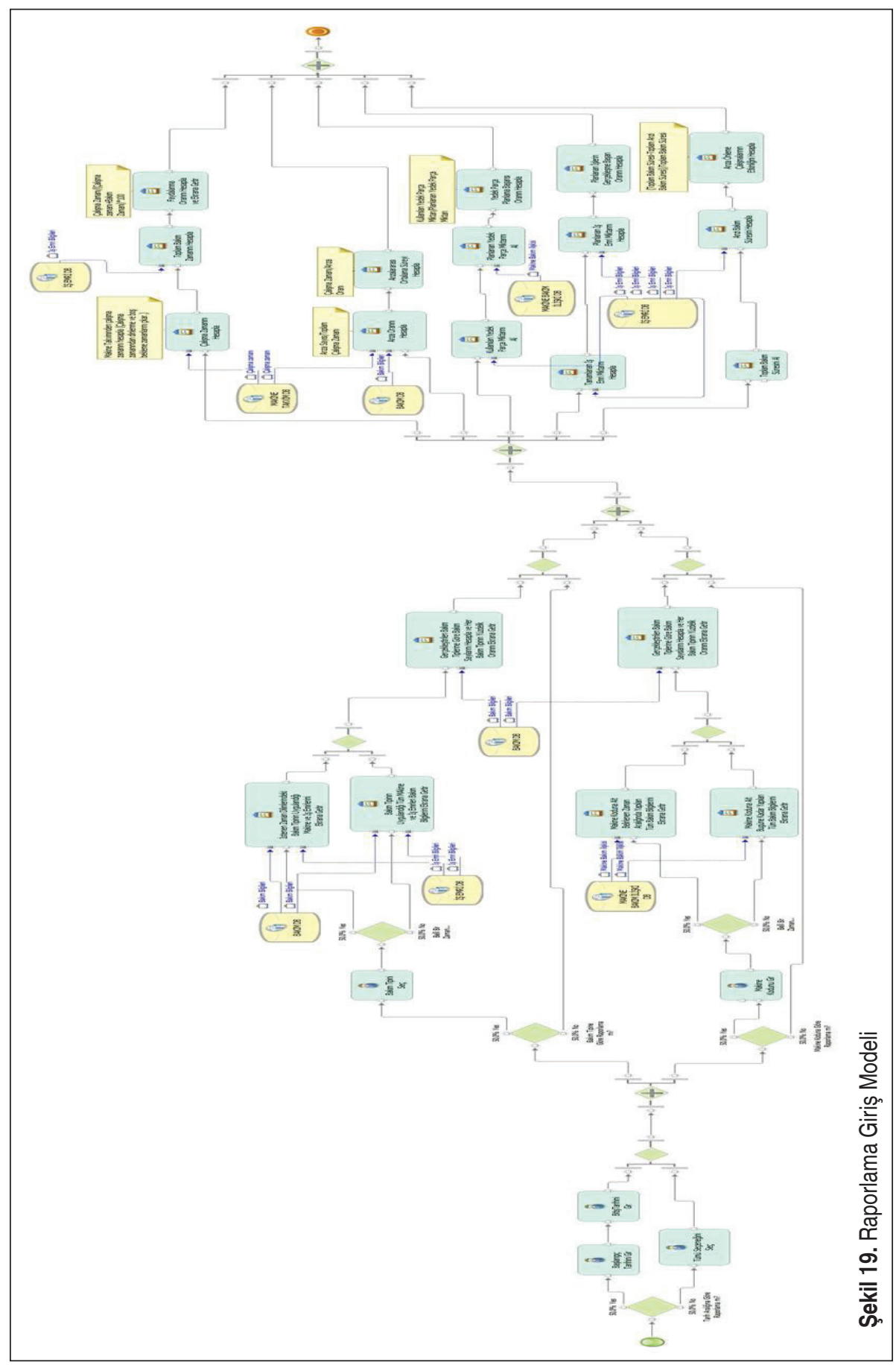


Raporlama Ekranı; Raporlama Giriş ve Raporlama Sonuç Karar alt süreçlerini içermektedir. Buna göre kullanıcı raporlama giriş ekranından istediği verileri çekecek ardından da sonuçları nasıl kullanacağına karar verebilecektir. Raporlama Sonuç Kararı yazdır ve göster işlemlerinden oluşmaktadır. Yani kullanıcı sonuç kullanımı kararında ekran gösterimi şeklinde ya da yazıcı vasıtasıyla doküman halinde görebilmektedir. Şekil 19, raporlama giriş modelini ayrıntılı olarak göstermektedir.

Raporlama ekranı ile gerçekleştirilen tüm bakım tipleri ve makinelere göre gerçekleştirilen bakımlar ayrıntılı olarak raporlanmaktadır. Aynı zamanda genel olarak bakım tiplerine göre gerçekleşen bakım sayıları ile hangi makineye hangi tipteki kaç adet bakımın yapıldığı, bakım süreleri gibi sayısal veriler ve bakımlar hakkında performans gösterge sonuçları raporlanmaktadır. Örneğin, günde iki vardiya olarak haftanın 5 günü çalışılmakta olan ve her vardiyanın 8 saatten oluştuğu bir işletmede her vardiya süresi içerisinde planlanmış 30 dakika duraklama süresi mevcuttur. Firmanın 2 haftal1k izleme sürecinde toplam çalışma süresi 9600 dakika olup planlanan duraklamalar (mola ve kalıp değişimleri vb.) ile 750 dakika makine çalışmamaktadır. Makine çalışma süresi 9600-750=8850 dakikadır. Bu süre zarfında makine toplamda 150 dakika bakım işlemi görmüş olduğunda;

Performans göstergelerinden Faydalanma Oranı $=(8850 /(8850+150)) \times 100=98.33$ yani makineden yaklaşık olarak \%98'lik bir verim almaktayız. Benzer şekilde daha uzun dönemler dikkate alındığında 4000 dakika toplam bakım için zaman harcanması ve bunun 150 dakikasının arızi bakım olması durumunda Arıza Önleme Çalışmalarının Etkinliği $=(4000-150) / 4000=0,9625$ 'tir. Yani arızalara karşı alınan önlemlerin yeterliliği yaklaşık \%96 oranındadır. Diğer performans gösterge hesaplamaları da yine sistem tarafından tüm verilerin sistemde kayıtlı olması neticesinde görsel ve hızlı bir şekilde raporlanarak çalışan ve yöneticilere planlama ve önlem alma çalışmalarının etkinliği ve maliyetleri hakkında bilgi sunabilecektir.

Tüm bu işlemlerin ardından artık bir bakım tanımı, detayı, makine ilişkisi, iş emri, iş emri kapama ve son olarak da raporlama işlemleri tamamlanmış olmaktadır. Sonuç olarak bakım süreci tamamlanmıştır.

\section{SONUÇ}

Bir işletmenin amacı temelde, işletme olanaklarından en iyi biçimde yararlanılmak suretiyle maliyetlerin en aza indirilmesi ve sürekli müşteri tatmini için kaliteli mal ve hizmet üretmesidir. Bu amacın sağlanabilmesi, ancak çok iyi bir stratejik planlama ve iş süreç analizi yapılması ile mümkün olacaktır. Bu şartlar göz önüne alındığında, üretimi aksatmadan maliyetlerin düşürülmesi, bir işletme için kaçırılmayacak bir firsat olmaktadır. Bakım Yönetimi Programları, kaçırılmayacak bu firsatın etkin olarak değerlendirilmesinde bir araç olarak karşımıza çıkmaktadır. Sonuç itibariyle günümüzün bilgi teknolojisinde hayatımızı kolaylaştırmak için daha fazla teknolo- 
jik ve bilişim alanındaki gelişmelerden yararlanmak zorundayız. Bu nedenle kişilere bağlı manuel olarak yürütülen süreçlerin iş süreç yönetimi ve iş süreç yeniden tasarımı gereksinimleri dikkate alınarak bilgi teknolojileri kullanılarak dijital ortamlara taşınması gerekmektedir. Bu çalışma ile bakım faaliyetlerinin firma itibarı ve satışların devamlılığı açısından önemi üzerinde durularak farkındalığın oluşturulması ve gerek yazılım dünyası gerekse kullanıcı bakış açısı ile bakım faaliyetlerinin istenen düzeyde ve performansta gerçekleştirebilmesi için iş süreç yönetiminden yararlanılarak yol gösterici olması ve uygulamaya katkı sağlaması amaçlanmıştır. Bir program veya otomasyon sisteminin oluşturulması öncesinde gerekli analiz ve araştırmaların gerçekleştirilmesi kaçınılmazdır. Bu sayede istenen yazılımlar istenen düzey ve nitelikte olabilecektir. Çalışma kapsamında bakım yönetim programının etkin bir şekilde yürütülmesinde kullanılacak ara yüzlerde olması gereken bilgilerin ve hangi amaçla bulunmaları gerektikleri hakkında kullanıcı ve yazılımcının yapması gereken işlemler BPMN mantığıyla sistemin ana modelinden alt modellerin oluşturulmasıyla açıklanmıştır. Bakım modülü bir bütün olarak ele alınıp çeşitli varsayımlar altında modellemeleri gerçekleştirilmiş ve raporlama alanıyla da bakım ve planlama performansları hakkında bilgilendirmeler tamamlanmıştır. Çalışma, bakım faaliyetlerinin belirli bir sektöre uygun olarak tasarlanması yerine genel yapıya uygun şekilde tasarlandığından farklı ERP sistemlerine adapte edilebilir ya da genel bir modül olarak kodlanabilir niteliktedir. Gelecek çalışmalarda sadece bakım modülü olarak değil üretimdeki tüm süreçler ayrıntılı olarak incelenerek sistem gereksinimleri, etkileşimleri ve etkileri ile birlikte iş modellenmesi ve raporlanması gerçekleştirilebilir. Aynı zamanda Üretim Yönetim Sistemlerinden (ÜYS) destek alınarak makine bakımı için gerekli ölçümlerin veri olarak sisteme girilmesi yerine IoT ve sensörler gibi araçlar yardımı ile toplanarak analiz işlemleri gerçekleştirilebilir.

\section{KAYNAKÇA}

1. KolayBPM 2021. BPM Nedir? https://www.kolaybpm.com/neden-bpm/bpm-nedir/. 18.01.2021

2. Kir, H., Erdogan, N. 2021. "A knowledge-intensive adaptive business process management framework". Information Systems, 95: p. 101639.

3. Köksal, M. 2015. Bakım Planlaması: Koruyucu Bakım - Kestirimci Bakım - Güvenilirlik. Vol. 2. İstanbul: Seçkin Yayıncılık.

4. Gürsoy, M.Ü., Çolak, U.C., Gökçe, M.H., Ötleş, S. 2019. “Endüstri için Kestirimci Bakım". International Journal of 3D Printing Technologies and Digital Industry, 3(1): p. 56-66.

5. Görener, A. 2013. "Bakım stratejilerinin bulanık karar ortamında seçimi için WSA ve TOPSIS yöntemlerinin uygulanması”. Sigma: Mühendislik ve Fen Bilimleri Dergisi, 31(3): p. 159-177. 
6. Uzun, A., Özdoğan, A. 2011. "Güvenirlik Analizlerine Dayalı Önleyici Bakım Planlanması”. Çukurova Üniversitesi Sosyal Bilimler Enstitüsü Dergisi, 20(1): p. 303-320.

7. Er, E. 2004. Bakım Yönetimi ve Bakım Yönetim Sistemlerinin Türkiye'de Uygulanma Düzeyi. İstanbul Teknik üniversitesi, Fen Bilimleri Enstitüsü.

8. Gürbüz, H., Cömert, E. 2012. "Bakım planlama faaliyetlerinde tamsayılı doğrusal programlama ve bir uygulama". Karadeniz Sosyal Bilimler Dergisi, 4(7): p. 101122.

9. Karaoğlan, İ., Altiparmak, F., Dengiz, B. 2007. "Tam Zamanında Üretim Sisteminde Bakım Politikalarının Etkisi”. Gazi Üniversitesi Mühendislik-Mimarlık Fakültesi Dergisi, 22(1): p. 181-189.

10. Görener, A. 2013. "Maintenance strategy selection by using WSA and TOPSIS methods under fuzzy decision environment". Sigma Journal of Engineering and Natural Sciences, 31(2): p. 159-177.

11. Anagün, A., Soy, E. 1999. Toplam Verimli Bakıma Geçişte İlişki Diyagramı Kullanımı, in IV. Ulusal Ekonometri ve İstatistik Sempozyumu. p. 435-447.

12. Baraçlı, H., Coşkun, S., Eser, A. 2001. "Toplam Kalite Programlarının Başarılı Olarak Uygulanabilmesinde Toplam Üretken Bakım Tekniği”. MMO Dergisi: p. 331-340.

13. Sherwin, D. 2000. "A review of overall models for maintenance management". Journal of quality in maintenance engineering, 6(3): p. 138-164.

14. Garg, A., Deshmukh, S. 2006. "Maintenance management: literature review and directions". Journal of quality in maintenance engineering.

15. Parida, A., Kumar, U., Galar, D., Stenström, C. 2015. "Performance measurement and management for maintenance: a literature review". Journal of Quality in Maintenance Engineering, 21(1): p. 2-33.

16. Şahin, B. 2003. Bilgisayar Destekli Bakım Yönetim Sistemleri ve Thy Bakım Yönetim Sistemi. İstanbul Teknik Üniversitesi, Fen Bilimleri Enstitüsü.

17. Türkan, Y., Esnaf, Ş. 2008. "Bakım yönetim çatısının oluşturulmasına yönelik bir uygulama”. VIII. Ulusal Üretim Araştırmaları Sempozyumu Bildiriler Kitabı: p. 613-624.

18. Akasah, Z., Amirudin, R., Alias, M. 2010. "Maintenance management process model for school buildings: An application of IDEF0 modelling methodology". Australian Journal of Civil Engineering, 8(1): p. 1-12.

19. Qing, B. 2012. "Design and Implementation of Locomotive Maintenance Process Management Information System". Computer Knowledge and Technology, 23: p. 5508-5510.

20. Kans, M. 2007. A literature review of computerised maintenance management sup- 
port, in 6th IMA International Conference on Modelling in Industrial Maintenance and Reliability. p. 96-101.

21. Pai, A., Rane, S. 2014. "Development and implementation of maintenance management module of enterprise resource planning in maintenance of power plant". International Journal of System Assurance Engineering and Management, 5(4): p. 534-543.

22. Castillo-Martinez, A., Medina-Merodio, J.-A., Gutierrez-Martinez, J.-M., Fernández-Sanz, L. 2021. "Proposal for a maintenance management system in industrial environments based on ISO 9001 and ISO 14001 standards". Computer Standards \& Interfaces, 73: p. 103453.

23. Boysweb 2021. BOYSWEB Bakım ve Varlık Yönetim Sistemi. http://www.yon. com.tr/boysweb.html. 18.01.2021

24. Karadede, A., Baykoç, Ö. 2006. "Kurumsal Kaynak Planlama (KKK) Uygulamasi Sonrasi Işletmelerin Yaşadiği Sorunlar”. Gazi Üniversitesi Mühendislik Mimarlık Fakültesi Dergisi, 21(1). 